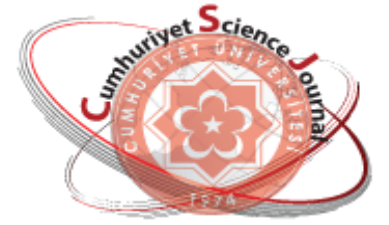

e-ISSN: $2587-246 X$

ISSN: $2587-2680$

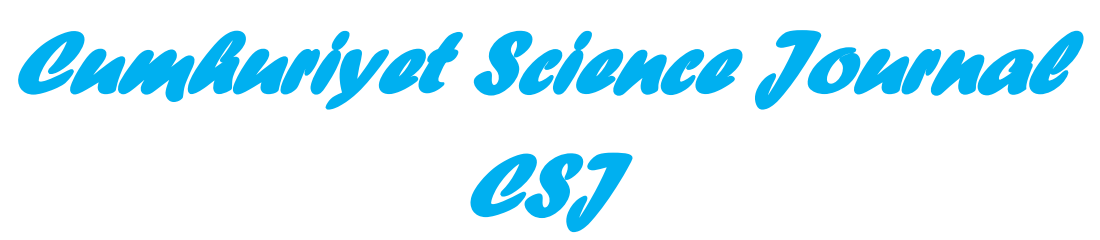

Cumhuriyet Sci. J., Vol.39-3(2018) 615-620

\title{
The Investigation of the Effects of Chlorpyrifos and 2,4- Dichlorophenoxyacetic Acid Application on Bovine Liver Catalase Activity
}

\author{
Hasan KARADA $\breve{G}$ \\ University of Adiyaman, Faculty of Science and Letters, Department of Chemistry, Adiyaman, TURKEY \\ Received: 09.11.2017; Accepted: 20.03.2018 \\ http://dx.doi.org/10.17776/csj.348453
}

\begin{abstract}
In this study, it was investigated whether different concentrations of organophosphate insecticide chlorpyrifos (CPF) and systemic herbicide 2,4-dichlorophenoxyacetic acid (2,4-D) on bovine liver catalase (CAT) activity cause any inhibitions or activations. For this purpose, 25, 50, 100, 250 and 500 ppm concentrations of CPF and 2,4-D were used. Following the applications of all tested concentrations of the both pesticides, the CAT activity elevated. Under the exposure of 25, 50, 100, 250 and $500 \mathrm{ppm}$ concentrations, \% CAT activity increases were calculated as $10.0 ; 6.2 ; 4.6 ; 6.9$ and 6.0 in CPF apllications, while these increases were calculated as $13.1 ; 10.3 ; 17.0 ; 24.4$ and 18.8 in 2,4-D applications, respectively. The present research indicated the elevations in CAT activity with 2,4-D were higher compared to CPF. This means that 2,4-D may have increased hydrogen peroxide production more than CPF.
\end{abstract}

Keywords: Catalase, chlorpyrifos, 2,4-dichlorophenoxyacetic acid, pesticide.

\section{Klorpirifos ve 2,4-Diklorofenoksiasetik Asit Uygulamasının Sığır Karaciğer Katalaz Aktivitesi Üzerine Etkilerinin İncelenmesi}

\begin{abstract}
Özet. Bu çalışmada, organofosfat insektisit klorpirifos (CPF) ve sistemik herbisit 2,4-diklorofenoksiasetik asit (2,4-D)'nin farklı konsantrasyonlarının, sığır karaciğer katalazı (CAT) üzerine herhangi bir inhibisyon ya da aktivasyona neden olup olmadığı araştırılmıştır. Bu amaçla CPF ve 2,4-D'nin 25, 50, 100, 250 ve 500 ppm konsantrasyonları kullanılmıştır. Her iki pestisitin test edilen tüm konsantrasyonlarının uygulanmasını takiben CAT aktivitesi artmıştır. 25, 50, 100, 250 ve 500 ppm konsantrasyonların etkisinde \% CAT aktivite artışları CPF uygulamalarında sırasıyla $10.0 ; 6.2 ; 4.6 ; 6.9$ ve 6.0 olarak hesaplanmışken bu artışlar 2,4-D uygulamalarında sırasıyla $13.1 ; 10.3 ; 17.0 ; 24.4$ ve 18.8 olarak hesaplanmıştır. Sunulan araştırma CAT aktivitesi artışlarının CPF'ye oranla 2,4-D uygulamalarında daha yüksek olduğunu göstermektedir. Bu 2,4D'nin hidrojen peroksit üretimini CPF'ye göre daha fazla artırmış olabileceği anlamına gelmektedir.
\end{abstract}

Anahtar Kelimeler: Katalaz, Klorpirifos, 2,4-diklorofenoksiasetik asit, pestisit.

\section{INTRODUCTION}

Chlorpyrifos

(O,O-diethyl

O-3,5,6-

trichloropyridin-2-yl phosphonothioate) (CPF) is organophosphate insecticide that inhibits acetylcholinesterase activity. CPF has been used both in a domestic and agricultural (outdoor) environment. Due to the fact that it has been blamed of causing retardation of the mental development of children, it was banned in most houses in the U.S in 2001 [1]. 2,4-
Dichlorophenoxyacetic acid (2,4-D) is systemic herbicide. It is used to control many types of broadleaf weeds. 2,4-D is possible carcinogen for humans and experimental animals [2] and leads to fertility problem at men [3].

Pesticides may cause formation of reactive oxygen species (ROS), which may lead to oxidative stress [4]. Antioxidant defense systems such as catalase (CAT), superoxide dismutase (SOD) and glutathione reductase (GR) are involved to prevent 
ROS toxicity [5]. Hydrogen peroxide is non-radical species of ROS [6]. Catalase from bovine liver (CAT) (E.C.1.11.1.6.) catalysis decomposition of hydrogen peroxide to water and oxygen [7]. Hydrogen peroxide damages cells. To prevent this, catalase is often used by cells [8].

Pesticides increase agricultural production, however, bioaccumulation through the food chain can finally become a risk to mammals because of their negative effects [9-12]. CPF and 2,4-D are used in agricultural areas. Both pesticides can be found together in the environment. CPF and 2,4-D are toxic to humans and animals [1, 2, 3]. Both compounds can alter enzyme activities. Because of that, it was designed a study on the effects of both pesticides on bovine liver catalase activity.

\section{MATERIAL AND METHOD}

\subsection{Chemicals}

Catalase from bovine liver (C-1345), chlorpyrifos $\left(\mathrm{C}_{9} \mathrm{H}_{11} \mathrm{Cl}_{3} \mathrm{NO}_{3} \mathrm{PS}\right.$ ) (45395) (Fig.1.a) and 2,4dichlorophenoxyacetic acid $\left(\mathrm{C}_{8} \mathrm{H}_{6} \mathrm{Cl}_{2} \mathrm{O}_{3}\right)($ D70724) (Fig.1.b) were bought from Sigma-Aldrich. All other chemicals used were analytical grade.

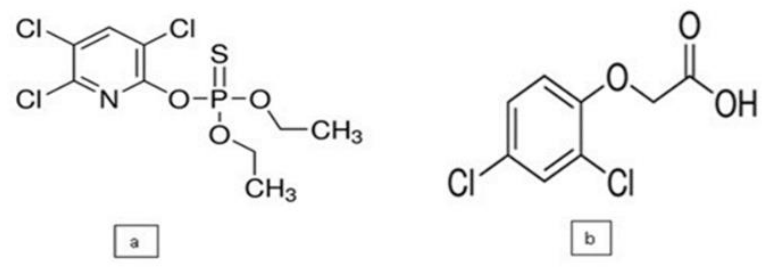

Figure 1. Structures of chlorpyrifos (a) and 2,4dichlorophenoxyacetic acid (b).

\subsection{Protein Determination}

The protein concentration was measured spectrophotometrically at $750 \mathrm{~nm}$ by the method of Lowry et al., 1951 [13]. Bovine serum albumin was used as a standard for the determination of protein concentration. For this purpose, four solutions were prepared: 1. Solution (A): $0.5 \mathrm{~g} \mathrm{CuSO}_{4} .5 \mathrm{H}_{2} \mathrm{O}$ and 1 $\mathrm{g}$ sodium citrate dihydrate were dissolved at distilled water and completed to $100 \mathrm{ml} ; 2$. Solution (B): $20 \mathrm{~g} \mathrm{Na}_{2} \mathrm{CO}_{3}$ and $4 \mathrm{~g} \mathrm{NaOH}$ were dissolved at distilled water and completed to 1000 $\mathrm{ml}$; 3. Solution (C): $1 \mathrm{ml}$ solution A was added to $50 \mathrm{ml}$ solution B; 4. Solution (D): $10 \mathrm{ml}$ Folin-
Ciocalteu was added to $10 \mathrm{ml}$ distilled water. After that, $2.5 \mathrm{ml}$ solution $\mathrm{C}$ was added to $0.5 \mathrm{ml}$ of prepared sample solution, vortexed, waited for 10 minutes at room temperature, mixed with $0.25 \mathrm{ml}$ solution $\mathrm{D}$, vortexed, waited for 30 minutes and read at $750 \mathrm{~nm}$ for protein concentration determination.

\subsection{CAT Activity}

CAT activity was measured according to the method of Lartillot et al., 1988 [14] which is studied by Bergmeyer, 1974 [15] previously. CAT activity was determined spectrophotometrically at $240 \mathrm{~nm}$ using a specific absorption coefficient at $0.040 \mathrm{~cm}^{2} \mu \mathrm{mol}^{-1} \quad \mathrm{H}_{2} \mathrm{O}_{2} .2 .5 \mathrm{~mL}$ of substrate solution of $10 \mathrm{mM}$ of $\mathrm{H}_{2} \mathrm{O}_{2}$ in $50 \mathrm{mM}, \mathrm{pH}=7.5$ phosphate buffer (Tukel and Alptekin, 2004 [16]) and $20 \mu \mathrm{L}$ of CAT solution of about $0.5 \mathrm{mg}$ protein $\mathrm{mL}^{-1}$ were mixed at $20{ }^{\circ} \mathrm{C}$ for $2 \mathrm{~min}$ and the reaction was stopped by adding $0.5 \mathrm{~mL}$ of $1 \mathrm{M} \mathrm{HCl}$. CAT activity was calculated as $\mu$ mol $\mathrm{H}_{2} \mathrm{O}_{2}$ decomposition. mg protein ${ }^{-1} \mathrm{~min}^{-1}$ or $\left(\mathrm{U} \mathrm{mg}^{-1}\right)$.

\subsection{Effect of Pesticides on Enzyme Activity}

Firstly, $5000 \mathrm{ppm}$ CPF was prepared in $2 \mathrm{ml}$ absolute ethyl alcohol and 5000 ppm 2,4-D dissolved in $2 \mathrm{ml} 95 \%$ ethyl alcohol. Because of low solubility of CPF and 2,4-D in water, CPF was prepared in absolute ethyl alcohol and 2,4-D was prepared in $95 \%$ ethyl alcohol, because 2,4-D is polar according to CPF. Then, these $5000 \mathrm{ppm}$ pesticide concentrations were arranged to 25,50 , 100, 250 and 500 ppm [17]. 25, 50, 100, 250 and $500 \mathrm{ppm}$ CPF with ethyl alcohol plus $700 \mu \mathrm{L}$ sample solution of about $0.5 \mathrm{mg}$ protein $\mathrm{mL}^{-1}$ were prepared and 25, 50, 100, 250 and 500 ppm 2,4-D with $95 \%$ ethyl alcohol plus $700 \mu \mathrm{L}$ sample solution of about $0.5 \mathrm{mg}$ protein $\mathrm{mL}^{-1}$ were prepared. At $0 \mathrm{ppm}$ or control, $300 \mu \mathrm{L}$ absolute ethyl alcohol plus $700 \mu \mathrm{L}$ sample solution for CPF were used and $300 \mu \mathrm{L} 95 \%$ ethyl alcohol plus 700 $\mu \mathrm{L}$ sample solution for 2,4-D were used. My solution volumes of enzyme and ethyl alcohol and pesticide were $1 \mathrm{ml}$ [17]. The mixture was incubated at room temperature for half hour. Then, activities of CAT were determined. 


\subsection{Data Analysis}

The data are presented as mean \pm standard deviation. For the statistical analyses, one-way analysis of variance (ANOVA) was used, followed by the Student Newman-Keul's test using the SPSS version 21 statistical software (SPSS Inc., Chicago, IL, USA). Differences were considered significant if $p<0.05$.

\section{RESULTS AND DISCUSSION}

\subsection{Effect of Chlorpyrifos on CAT Activity}

Different CPF concentrations with CAT enzyme solutions were prepared, then, activities of CAT were measured as reported in Table 1. Compared to the control activity, there are statistical differences between all CAT activities which interacted with the CPF $(\mathrm{p}<0.05, \mathrm{n}=3)$. Under the exposure of 25, 50, 100, 250 and $500 \mathrm{ppm} \mathrm{CPF}$ concentrations, \% CAT activity increases were calculated as $10.0 ; 6.2 ; 4.6 ; 6.9$ and $6.0 \%$, respectively.

\subsection{Effect of 2,4-Dichlorophenoxyacetic acid on CAT Activity}

Different 2,4-D concentrations with CAT enzyme solutions were prepared, then, activities of CAT were measured as reported in Table 1. When compared to the control activity, there are statistical differences between all CAT activities which interacted with the 2,4-D $(\mathrm{p}<0.05, \mathrm{n}=3)$. Under the exposure of $25,50,100,250$ and 500 ppm 2,4-D concentrations, \% CAT activity increases were calculated as $13.1 ; 10.3 ; 17.0 ; 24.4$ and $18.8 \%$, respectively.

Table 1. Effect of chlorpyrifos and 2,4-dichlorophenoxyacetic acid concentrations on catalase activity.

\begin{tabular}{ccc}
\hline & Effect of CPF on & Effect of \\
Concentration $(\mathrm{ppm})$ & CAT Activity \pm SD $\left(\mathrm{U} \mathrm{mg}^{-1}\right)$ & $2,4-\mathrm{D}$ on CAT Activity \pm SD $\left(\mathrm{U} \mathrm{mg}^{-1}\right)$ \\
\hline 0 & $1426 \pm 38^{\mathrm{a}}$ & $1297 \pm 15^{\mathrm{a}}$ \\
25 & $1569 \pm 12^{\mathrm{b}}$ & $1467 \pm 9^{\mathrm{b}}$ \\
50 & $1514 \pm 19^{\mathrm{c}}$ & $1430 \pm 24^{\mathrm{c}}$ \\
100 & $1491 \pm 12^{\mathrm{c}}$ & $1518 \pm 16^{\mathrm{d}}$ \\
250 & $1524 \pm 11^{\mathrm{c}}$ & $1614 \pm 7^{\mathrm{e}}$ \\
500 & $1512 \pm 6^{\mathrm{c}}$ & $1541 \pm 18^{\mathrm{d}}$ \\
\hline
\end{tabular}

Data is expressed as mean \pm standard deviation $(n=3)$. At the table "a, b, c, d and e" letters are used for differences of activity levels. There are statistical differences between data which are shown with different letters $(\mathrm{p}<0.05)$.

\subsection{Comparison of Chlorpyrifos and 2,4- Dichlorophenoxyacetic acid on CAT activity}

The percentages of both CAT activities were increased under the exposure of 25, 50, 100, 250 and 500 ppm CPF and 2,4-D concentrations. But, increasing CAT activity with 2,4-D was higher compared to CPF. 2,4-D increased the percentages of CAT activity more than 3.13 times compared to that of CPF at 500 ppm (Fig.2). 


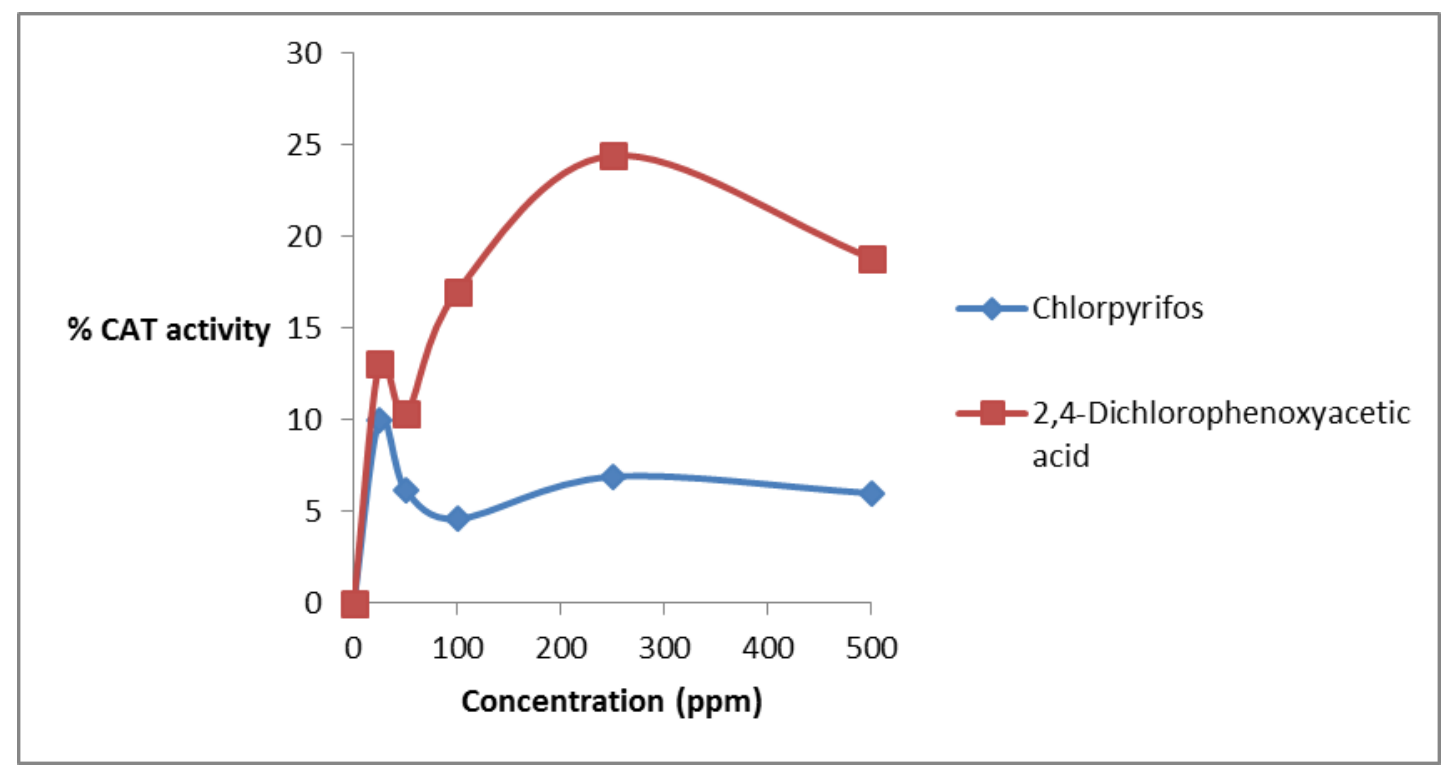

Figure 2. Comparison of chlorpyrifos and 2,4-dichlorophenoxyacetic acid on catalase activity.

Reactive oxygen species (ROS) generation increases in pesticide toxicity [18]. Hydrogen peroxide is a form of ROS. When hydrogen peroxide occurs, CAT converts hydrogen peroxide to water and oxygen. Increases at CAT activity might be response to production of hydrogen peroxide or ROS [19].

Karadag et al. [20-22] applied various pesticides (cyprodinil and fludioxonil; deltamethrin and alpha cypermethrin; lambda cyhalothrin and fenthion) on bovine liver catalase. When they applied pesticide concentrations from 0 to $500 \mathrm{ppm}$, they reported enzyme inhibitions. In contrast to these, in the present study, the enzyme activation was observed.

CPF increased CAT activity. For instance, Cacciatore et al., 2015 [23] found increased CAT activity ( $22 \%$ of increase) in the soft tissues of freshwater gastropod (Planorbarius corneus) after $7.5 \mu \mathrm{g} \mathrm{L}^{-1}$ of $\mathrm{CPF}$ exposure. Similarly, Wu et al., 2011 [24] showed that $\mathrm{CPF}$ at the concentration of $0.12 \mu \mathrm{g} \mu \mathrm{L}^{-1}$ increased significantly CAT activity by $85 \%$ of the control in thunberg (Oxya chinensis). In the same way, Kaur and Sandhu, 2008 [25] exposed buffalo (Bubalus bubalis) calves to $\mathrm{CPF}$ at a dose of $0.05 \mathrm{mg} \mathrm{kg}^{-1}$ per day for 20 consecutive weeks. They found that the enzymatic activity of catalase (CAT) $(63.8 \%)$ elevated. Jin et al., 2015 [26] showed considerable increases of CAT activity at the 30 and $100 \mu \mathrm{g} \mathrm{L}^{-1} \mathrm{CPF}$ groups in the larval zebrafish (Danio rerio). When Aly et al. 2010 [27] administered orally $13.495 \mathrm{mg} / \mathrm{kg}$ (1/10 $\mathrm{LD}_{50}$ ) CPF to male mice, they reported 1.41 fold CAT activation. This activation is higher compared to the findings of this study. After application of 25, 50, 100, 250 and $500 \mathrm{ppm}$ CPF concentrations, 1.100, 1.062, 1.046, $1.069,1.060$ fold CAT activations were found respectively.

24-D increased CAT activity as well. For example, Oruc et al., 2004 [28] treated 2,4-D to Cyprinus carpio for $96 \mathrm{~h}$. They indicated 1.66 fold rise in catalase activity in kidney of Cyprinus carpio. At another work, Atamaniuk et al., 2013 [29] treated $100 \mathrm{mg} \mathrm{L}^{-1}$ of 2,4-D to goldfish (Carassius auratus). 2,4-D increased catalase activity (by $41 \%$ or 1.41 fold). This activations are higher compared to the findings of present study. After application of 25, 50, 100, 250 and 500 ppm 2,4-D concentrations, $1.131 ; 1.103 ; 1.170 ; 1.244$ and 1.188 fold CAT activations were found respectively. 


\section{CONCLUSION}

The experiments were carried out to determine the effect of CPF and 2,4-D pesticides on bovine liver catalase activity. Both pesticides activated CAT activity at 25, 50, 100, 250 and $500 \mathrm{ppm}$ pesticide concentrations. These results indicate that after the exposure of $\mathrm{CPF}$ and 2,4-D pesticides in living organism, hydrogen peroxide which is harmful for cells might be produced. In conclusion, when hydrogen peroxide increases due to pesticide exposure, catalase enzyme activity increases too. These results at the same time important for defense system of cells.

\section{REFERENCES}

[1]. Israel B., Common Insecticide May Harm Boys' Brains More Than Girls. Scientific American 2012; August 21.

[2]. Loomis D., Carcinogenicity of lindane, DDT, and 2,4-dichlorophenoxyacetic acid, The Lancet Oncology 2015; 16(8): 891-892.

[3]. The National Institute for Occupational Safety and Health (NIOSH), The Effects of Workplace Hazards on Male Reproductive Health 2014; Accessed date: November 2017.

[4]. Banerjee B.D., Seth V., Ahmed R.S., Pesticide-induced oxidative stress: perspectives and trends, Rev. Environ. Health, 2001; 16: 1-40.

[5]. Attia, A.A., ElMazoudy, R.H., Nahla S. El-Shenawy, N.S., Antioxidant role of propolis extract against oxidative damage of testicular tissue induced by insecticide chlorpyrifos in rats, Pesticide Biochemistry and Physiology, 2012; 103: 87-93.

[6]. Halliwell B., Gutteridge J. M. C., Free Radicals In Biology And Medicine. Third Edition, Oxford University Press., New York, 1999.

[7]. Chelikani P., Fita I., Loewen P.C., Diversity of structures and properties among catalases, Cell Mol Life Sci. 2004; 61 (2): 192-208.

[8]. Gaetani G., Ferraris A., Rolfo M., Mangerini R., Arena S., Kirkman H., Predominant role of catalase in the disposal of hydrogen peroxide within human erythrocytes. Blood 1996; 87 (4): 1595-9.

[9]. Jardim A.N.O., Caldas E.D., Brazilian monitoring programs for pesticide residues in food-Results from 2001 to 2010, Food Control, 2012; 25: 607-616.

[10]. Lozowicka B., Kaczynski P., Paritova A.E., Kuzembekova G.B., Abzhalieva A.B., Sarsembayeva N.B., Alihan K., Pesticide residues in grain from Kazakhstan and potential health risks associated with exposure to detected pesticides, Food and Chemical Toxicology, 2014; 64: 238-248.

[11]. Skretteberg L.G., Lyran B., Holen B., Jansson A., Fohgelberg P., Siivinen K., Andersen J.H., Jensen B.H., Pesticide residues in food of plant origin from Southeast Asia-A Nordic Project, Food Control, 2015; 51: 225-235.

[12]. Liu Y., Li S., Ni Z., Qu M., Zhong D., Ye C., Fubin Tang pesticides in persimmons, jujubes and soil from China: Residue levels, risk assessment and relationship between fruits and soils, Science of the Total Environment, 2016; 542: 620-628.

[13]. Lowry O.H., Rosebrough N.J., Farr A.L., Randall R.J., Protein measurements with the folin phenol reagent, The Journal of Biological Chemistry, 1951; 193: 265-275.

[14]. Lartillot S., Kadziora P., Athios A., Purification and characterization of new fungal catalase, Prep Biochem, 1988; 18(3): 241-246.

[15]. Bergmeyer H.U., In: Bergmeyer, HU. (Ed.), Methods of Enzymatic Analysis. 2nd ed, vol.1., Academic press, New York, USA, 1974; 438 p. 
[16]. Tukel S.S., Alptekin O., Immobilization and kinetics of catalase onto magnesium silicate, Process Biochemistry, 2004; 39: 2149-2155.

[17]. Karadag H., Bilgin R., Effect of cyprodinil and fludioxonil pesticides on human superoxide dismutase, Asian Journal of Chemistry, 2010; 22(10): 8147-8154.

[18]. John S., Kale M., Rathore N., Bhatnagar D., Protective effect of vitamin E in dimethoate and malathion induced oxidative stress in rat erythrocytes, The Journal of Nutritional Biochemistry, 2001; 12(9): 500-504.

[19]. Ritola O., Livingstone D.R., Peters L.D., Lindstrom-Seppa P., Antioxidant processes are affected in juvenile rainbow trout (Oncorhynchus mykiss) exposed to ozone and oxygensupersaturated water, Aquaculture 2002; 210: 1-19.

[20]. Karadag H., Ozhan F., Effect of cyprodinil and fludioxonil pesticides on bovine liver Catalase activity, Biotechnology \& Biotechnological Equipment, 2015; 29(1): 40-44.

[21]. Karadag H. and Uluca H., Effect of deltamethrin and alpha cypermethrin pesticides on bovine liver catalase activity, Fresenius Environmental Bulletin, 2015; 24(11): 3562-3566.

[22]. Karadag H., Kaplan F., Effect of lambda cyhalothrin and fenthion pesticides on bovine liver catalase activity, Fresenius Environmental Bulletin, 2016; 25(8): 3012-3016.

[23]. Cacciatore L.C., Nemirovsky S.I., Guerrero N.R.V., Cochón A.C., Azinphos-methyl and chlorpyrifos, alone or in a binary mixture, produce oxidative stress and lipid peroxidation in the freshwater gastropod Planorbarius corneus, Aquatic Toxicology, 2015; 167: 12-19.

[24]. Wu H., Zhang R., Liu J., Guo Y., Ma E., Effects of malathion and chlorpyrifos on acetylcholinesterase and antioxidant defense system in Oxya chinensis (Thunberg) (Orthoptera: Acrididae), Chemosphere, 2011; 83: 599-604.

[25]. Kaur R., Sandhu H.S., In vivo changes in antioxidant system and protective role of selenium in chlorpyrifos-induced subchronic toxicity in bubalus bubalis, Environmental Toxicology and Pharmacology 2008; 26: 45-48.

[26]. Jin Y., Liu Z., Peng T., Fu Z., The toxicity of chlorpyrifos on the early life stage of zebrafish: A survey on the endpoints at development, locomotor behavior, oxidative stress and İmmunotoxicity, Fish \& Shellfish Immunology, 43 (2015) 405-414.

[27]. Aly N., EL-Gendy K., Mahmoud F., ElSebae A.K, Protective effect of vitamin $\mathrm{C}$ against chlorpyrifos oxidative stress in male mice, Pesticide Biochemistry and Physiology, 97 (2010) 7-12.

[28]. Oruc E.O., Sevgiler Y., Uner N., Tissuespecific oxidative stress responses in fish exposed to 2,4-D and azinphosmethyl, Comparative Biochemistry and Physiology, Part C 137 (2004) 43-51.

[29]. Atamaniuk T.M., Kubrak O.I., Storey K.B., Lushchak V.I., Oxidative stress as a Mechanism for toxicity of 2,4dichlorophenoxyacetic acid (2,4-D): studies with goldfish gills, Ecotoxicology 22 (2013) 1498-1508. 